\title{
Pristane in the marine environment ${ }^{1}$
}

\author{
Max Blumer, Michael M. Mullin and David W. Thomas \\ Woods Hole Oceanographic Institution, Woods Hole, Mass., U.S.A.
}

KURZFASSUNG: Pristan in der marinen Umwelt. Pristan $(2,6,10,14$-Tetramethylpentadecan) kommt in niedriger Konzentration in manchen planktonischen Tieren des Golfs von Maine, USA, und der Gewässer des kontinentalen Schelfes vor. Dieser Kohlenwasserstoff leitet sich vermutlich vom Phytol in der Nahrung der planktonischen Herbivoren ab. Seine Konzentration ist ungewöhnlich hoch in Calanus finmarchicus, C. glacialis und C. byperboreus, wo er möglicherweise als auftriebsregulierende Substanz in Hungerzeiten wichtig ist. Arten, wie Paraeuchaeta norvegica, welche Calanus verzehren, stellen sekundäre Pristanquellen innerhalb der marinen Nahrungskette dar. Die pro Calanus-Individuum angetroffene Pristanmenge könnte als Indikator für die gesamte Nahrungsassimilation dienen. Pristan und andere artspezifische Stoffe können in das die Individuen umgebende Wasser gelangen und dann als biochemische Markierungs-Substanzen dienen.

\section{INTRODUCTION}

Hydrocarbons are minor but ubiquitous components of the marine environment (GERARDE \& GERARDE 1961). Within the wide range of organic compounds present in the sea, they occupy a special position because of their relative chemical and biological inertness. Though hydrocarbons are eventually degraded by marine bacteria (Stewart et al. 1959, STEwart \& Kallio 1959, FinNerty et al. 1962), they are not as rapidly utilized as some other organic substrates, such as amino acids or carbohydrates. Therefore, they should have a relatively slow turnover rate and, correspondingly, a long residence time in the ocean.

Fossil hydrocarbons are introduced into the sea through submarine seepage of petroleum from the sediments or as pollution on a macroscopic or microscopic molecular level from human activities. In regard to hydrocarbon type- and molecular weight-distribution, the fossil hydrocarbons in petroleum and its derivatives are better known than the recent hydrocarbons of biochemical origin.

These recent hydrocarbons are encountered in many marine sediments and are present in most, if not all, marine organisms and in the sea water itself. The hydrocarbons of recent marine inshore sediments.(SMith 1954, Stevens et al. 1956, MenNSCHEIN 1959) and of some deep basins in the continental shelf (EMERY 1960) have been relatively well studied. Little is known about the presence of hydrocarbons in sediments deposited under high redox potential (ThOMAs \& BLumer 1964); sediments

1 Contribution No. 1438 of the Woods Hole Oceanographic Institution. 
of the slope and abyssal plains have never been investigated. In the marine biosphere, hydrocarbons have been encountered in oysters (CAHNMANN \& KURATsune 1957), barnacles (ZeChmeister \& Koe 1952), gorgonians (Ciereszko et al. 1963), and several fishes and whales (Table 1), but the planktonic organisms which make up the bulk of the biomass in the oceans have not been extensively studied. Lipid analysis of mixed marine plankton (Collin et al. 1934) and diatoms (Clarke \& MAZUR 1941) suggested the presence of hydrocarbons in the unsaponifiable fraction. Saturated hydrocarbons, including normal paraffins, have been identified in algal extracts (SMITH 1954, STEVENS et al. 1956), but the presence of aromatic hydrocarbons remains controversial. Hydrocarbons also occur in zooplankton (Collin et al. 1934) but, as in the case of phytoplankton, little is known about their structural composition and possible variations of their composition in different species.

The hydrocarbon pristane, with which the present investigation is mainly concerned, was named by Toyama (1923), who discovered it in the liver oil of the basking shark and other elasmobranchs. It has since been described from several marine

Table 1

Occurence of pristane in nature

\begin{tabular}{|c|c|c|}
\hline Occurrence & Authors & \\
\hline $\begin{array}{l}\text { Cetorbinus maximus GUNNAR } \\
\text { (basking shark) } \\
\text { Semnorbinus licha BONATERRE } \\
\text { Mixed oil of Zameus squamelosus } \\
\text { Centroscymnus oresonii } \\
\text { Clamydoselacbus anguineu GorMan } \\
\text { Centropborus spec. (various sharks) }\end{array}$ & Y. Toyama & 1923 \\
\hline $\begin{array}{l}\text { Herring oil, mixed oil from herring } \\
\text { and sardine, sperm whale oil }\end{array}$ & Y. Toyama \& T. Tsuchiya & 1935 \\
\hline Basking shark, liver & S. SchMidT-NiELsEN \& K.T. ERIKSEN & 1944 \\
\hline Basking shark, liver & N. A. SÖRENSEN \& J. MEHLUM & 1948 \\
\hline Ambergris & E. Lederer \& J. Pliva & 1951 \\
\hline Sperm whale, liver & T. TSUCHIYA \& R. KanEKo & 1951 \\
\hline Basking shark, liver & T. Tsuchiya, R. Kaneko \& T. Endo & 1952 \\
\hline Basking shark, liver oil & T. TsujINo \& K. KrKuch & 1953 \\
\hline Herring oil & G. LAMBERTSEN \& R. T. HOLMAN & 1963 \\
\hline Zooplankton & $\begin{array}{l}\text { M. Blumer, M. M. Muldin \& } \\
\text { D. W. Thomas }\end{array}$ & 1963 \\
\hline $\begin{array}{l}\text { Lepidocybium flavobrunnium (SMITH) } \\
\text { in meat } 0.0073 \% \text { wet weight } \\
\text { in liver } 0.0095 \% \text { - (Gemphylidae, } \\
\text { "snake mackerels") }\end{array}$ & $\begin{array}{l}\text { M. BLUMER \& R. H. BackUS, } \\
\text { unpublished }\end{array}$ & 1963 \\
\hline Homarus americanus (lobster) & M. BLUMER, unpublished & 1963 \\
\hline Petroleum & R. A. Dean \& E. V. Whrtehead & 1961 \\
\hline Petroleum & $\begin{array}{l}\text { J. G. Bendoraitis, B. L. Brown } 8 x \\
\text { L. S. Hepner }\end{array}$ & 1962 \\
\hline Oil shale & J. J. Cummins \& W. E. Rorinson & 1963 \\
\hline
\end{tabular}


organisms and their oils (Table 1). SöRENSEN and coworkers $(1948,1949)$ established the structure of pristane and synthesized several related compounds. These investigators considered it unlikely that pristane was a product of synthetic processes in the elasmobranchs, and suggested that the pristane was produced by zooplankters or other organisms eaten by the sharks. The discovery of relatively large quantities of pristane in copepods of the genus Calanus (BLUmer et al. 1963) supports this suggestion.

\section{METHODS}

\section{Sampling}

Zooplankton was collected in the upper $200 \mathrm{~m}$ with a \# 2-mesh plankton net on August 14,1962 , at $42^{0} 50^{\prime} \mathrm{N}, 69^{\circ} 50^{\prime} \mathrm{W}$; on April 9-17, 1963, at 42014' N, 64030' W and $41^{\circ} 39^{\prime} \mathrm{N}, 6^{\prime} \mathrm{O}^{\prime} 7^{\prime} \mathrm{W}$; and on June 29,1963 , at $39^{\circ} 42^{\prime} \mathrm{N}, 69^{\circ} 32^{\prime} \mathrm{W}$. Collections were frozen on shipboard and returned to the laboratory for analysis. In order to prevent contamination of one species by lipids from damaged individuals of another species, most of the animals from the two latter collections were sorted into species and developmental stage on shipboard; these were then frozen separately. There was no evidence for contamination in the earlier collections, but free lipid was occasionally observed in samples which had been repeatedly thawed and refrozen. Other collections were preserved in 5\% formaldehyde for counting and dry weight determinations.

\section{Dry weight and lipid determinations}

Dry weight measurements were made on frozen or formaldehyde-preserved animals which were rinsed briefly with distilled water over a sintered glass filter to remove external salts, and dried at $60^{\circ} \mathrm{C}$ in an oven for 24 hours before weighing (Lovegrove 1962). Total lipid content was determined by extracting the frozen, dried animals with acetone in a small Soxhlet apparatus for 12 hours and measuring the weight loss. In general, at least two groups of animals of each species and stage were analysed, involving 10-250 individuals for the lipid determination and 2-15 individuals for the separate pristane analysis.

\section{The isolation of pristane}

The total lipids from frozen, unsorted zooplankton samples collected in the Gulf of Maine were prepared by homogenizing the thawed animals in a mixture of benzenemethanol (3:7). The extracts were filtered and washed with water to remove the salts and much of the methanol. The remaining benzene solution of the lipids was dried with anhydrous sodium sulfate and concentrated in a rotating evaporator. Three $\mathrm{ml}$ of the remaining oil were charged to a pentane-wet column consisting of $30 \mathrm{ml}$ silica gel and $15 \mathrm{ml}$ alumina. The saturated hydrocarbons were eluted with $75 \mathrm{ml}$-pentane 
and concentrated by evaporation of the solvent. Pristane was isolated from this fraction on a small scale by gas chromatography; larger samples were distilled in an effcient micromolecular still (BLumer 1962). Distillation led to nearly pure pristane since hydrocarbons of close boiling point are present only in minor amounts.

\section{The determination of pristane}

a.) Extraction of the lipids and isolation of the saturated bydrocarbons. One or more animals were transferred to a tissue grinder and suspended in $1 \mathrm{ml} \mathrm{n}$-pentane (redistilled). The animal was crushed, and grinding was continued for one minute for complete transfer of the lipids to the solvent. Pestle and walls of the homogenizer were washed with $1 \mathrm{ml}$ pentane; the solution was then transferred by micropipette to a $5 \mathrm{ml}$ evaporating flask (VANDENHEUVEL 1963). Tissue grinder and pipette were washed with an additional $0.5 \mathrm{ml}$ pentane. The extract was concentrated by evaporation in a rotating evaporator at room temperature, using a moderate vacuum.

Chromatographic isolation of the pristane from the lipids previous to gas chromatography was rarely necessary because of its high relative concentration and the ease with which it was identified from retention time or by the addition of an internal standard. If desired, the saturated hydrocarbons were isolated as follows: A chromatographic column was prepared by cutting a $0.1 \mathrm{ml}$ graduated pipette $(0.25 \mathrm{~mm}$ i. d.) at the $0.8 \mathrm{ml}$ mark from the tip. A small cotton plug was inserted into the tip and the column was vacuum-packed with $0.15 \mathrm{ml}$ silica gel (Davison Grade 922, through 200 mesh, The Davison Chemical Company, Baltimore 3, Md.), activated at $120^{\circ} \mathrm{C}$ and $0.05 \mathrm{ml}$ alumina, activated at $220^{\circ} \mathrm{C}$ (Al-0102-P, The Harshaw Chemical Company, Cleveland 6, Ohio). Normal pentane $(0.5 \mathrm{ml})$ was forced into the column under pressure to remove the air. The liquid level was adjusted to the top of the adsorbent. The lipids from one or several animals were dissolved in not more than $0.020 \mathrm{ml}$ pentane and transferred to the adsorbent bed by microsyringe (Hamilton Gas-Tight $0.1 \mathrm{ml}$ syringe). The solution was forced into the column; the evaporating tube and syringe were washed with an additional $0.02 \mathrm{ml}$ pentane which were transferred to the column.

Pentane $(0.5 \mathrm{ml})$ was added for the elution of the saturated hydrocarbons. The eluate was collected in a $1 \mathrm{ml}$ evaporating flask until the solvent level reached the top of the column. The tip of the column was washed into the flask with pentane. The

Table 2

Recovery of pristane in chromatography

\begin{tabular}{|lcc|}
\hline Fraction & \% Pristane recovered & \% Pyrene recovered \\
\hline 1. $0.5 \mathrm{ml}$ n-pentane & 99.2 & not detectable \\
2. $0.5 \mathrm{ml}$ n-pentane-benzene, $3: 2$ & 0.8 & 100 \\
3. $0.8 \mathrm{ml}$ benzene-methanol, $4: 1$ & not detectable & not detectable \\
\hline
\end{tabular}

Sample: $0.001 \mathrm{~g}$ pristane and $0.001 \mathrm{~g}$ pyrene, dissolved in $0.001 \mathrm{ml}$ iso-octane. Column: $0.15 \mathrm{ml}$ silica gel, covered with $0.05 \mathrm{ml}$ alumina, activated at $220^{\circ} \mathrm{C}$. 
aromatic hydrocarbons and the nonhydrocarbons were collected subsequently by elution with $0.5 \mathrm{ml}$ pentane benzene $(3: 2)$ and $0.8 \mathrm{ml}$ benzene-nethanol $(4: 1)$. After evaporation the eluates ready for gas chromatography.

This procedure led to a quantitative recovery and separation of the pristane from aromatic hydrocarbons and nonhydrocarbons (Table 2).

b.) Gas Chromatograpby. The gas chromatographic apparatus employed in this work consisted of a Model A-600-B Aerograph with hydrogen flame detector, a Model A-650 hydrogen generator and an A-325 linear temperature programmer (Wilkens Instrument and Research, Inc., Walnut Creek Calif.). A Leeds and Northrup Speedomax Recorder ( $1 \mathrm{mv}$ full scale) was utilized in conjunction with a Model $50 \mathrm{~F} \& \mathrm{M}$ automatic attenuator (F \& M Scientific Corporation, Avondale, Pa.).

The separations were performed on $6 \mathrm{ft} . \times 1 / 8$ inch stainless steel columns, packed with 80-100 mesh Chromosorb W, treated with trimethylchlorosilane and coated with $5 \%$ Dow Corning RTV 502 silicone rubber (weight based on silicone rubber after removal of filler by centrifugation in benzene solution). The columns were operated at a flow rate of $24 \mathrm{ml} \mathrm{N} / \mathrm{min}$., the hydrogen flow to the detector was $17 \mathrm{ml} / \mathrm{min}$. Samples dissolved in $\mathrm{CS}_{2}$ or n-pentane were injected into the cold column. Slow injection $(0.015 \mathrm{ml} / \mathrm{min})$ was necessary with pentane to prevent overloading of the column and tailing of the solvent peak. The temperature was programmed at $8 \% \mathrm{~min}$. After elution of the pristane at about $200^{\circ} \mathrm{C}$ the column temperature was rapidly raised to $300-310^{\circ} \mathrm{C}$ in order to elute higher boiling compounds which would accumulate in the column and affect the retention times. Occasional cleaning of the column by repeated injection of $0.01 \mathrm{ml}$ water at $300^{\circ} \mathrm{C}$ prolonged its useful life.

Pristane was quantitatively determined from peak areas (peak height times width at half height). The long term reproducibility with pristane standards was $\pm 1.5 \%$. Samples were trapped from the column by the following method: The flame cylinder was removed and an adapter made from a hypodermic needle (20 gauge), cut to $10 \mathrm{~mm}$ length, was slipped over the quartz flame tip. A rim of silicone rubber (Dow Corning RTV 731) around the base of the hub served as a seal. The needle was heated with a few turns of resistance wire. A $30 \mathrm{~cm} \times 1.5 \mathrm{~mm}$ glass capillary, slipped over the needle, was used to collect the sample. Insertion of the collector and reinsertion of the flame cylinder after the collection required less than 30 seconds; the hydrogen and nitrogen flow need not be reduced during the collection. Spectra: Mass spectra were determined with a CEC 21-103C mass spectrometer equipped with a stainless steel inlet system at $140^{\circ} \mathrm{C}$. The ionizing potential was $70 \mathrm{e}$. v. The infra red spectra were obtained on a Perkin Elmer Model 21 Spectrophotometer.

\section{RESULTS}

\section{Pristane in zooplankton}

The hydrocarbons of an unsorted, frozen zooplankton sample from the Gulf of Maine were analysed by gas chromatography. A single compound was unexpectedly predominant in the fraction boiling below $400^{\circ} \mathrm{C}$. A zooplankton sample taken in 
the inshore waters near Woods Hole showed no such predominance of a single compound. This immediately suggested the association of this particular hydrocarbon with organisms present in the Gulf of Maine but not in Woods Hole waters, and led us to attempt the identification of this compound and its specific source.

Chromatography of the zooplankton extract over silica gel under standardized conditions (see Methods) concentrated the unknown compound in the saturated hydrocarbon fraction. In gas chromatography, it eluted from a nonpolar (silicone rubber) column simultaneously with normal heptadecane and on a more polar column (20 M Carbowax), the unknown emerged between normal hexadecane and heptadecane. This behavior identified the compound as a branched saturated hydrocarbon of more than seventeen carbon atoms.

Pure samples of this hydrocarbon were prepared by chromatography of the zooplankton extract over silica gel, followed by gas chromatography and trapping of the hydrocarbon as it eluted from the column. Larger samples were obtained by distillation of the saturated hydrocarbon concentrate in an efficient micromolecular still (BLumer 1962). A molecular weight of 268 was determined by mass spectrometry and this, together with the near infrared spectrum, indicated a highly branched isomer of nonadecane, $\mathrm{C}_{19} \mathrm{H}_{40}$. The extremely low melting point - there was no crystallization even at dry ice temperature - suggested that the hydrocarbon might be pristane $(2,6,10,14$-tetramethylpentadecane). This was confirmed by the agreement of the infra red- and mass-spectra with published data (Pliva \& Sörensen 1950, BendoRAITIS et al. 1961) and with spectra obtained from commercial pristane.

In order to determine the organisms responsible for the high pristane content in the unsorted samples from the Gulf of Maine, several individuals of different species were picked out of a sample collected and frozen on August 14, $1962\left(42^{\circ} 50^{\prime} \mathrm{N}\right.$, $64^{0} 50^{\prime} \mathrm{W}$ ). Large concentrations of pristane were found in the copepod Calanus fin marchicus, the dominant organism in terms of biomass in that sample, and in the related species C. glacialis and C. byperboreus (BLUMER et al. 1963).

Table 3 summarizes the analyses of total lipid and pristane of various species of zooplankton from the Gulf of Maine and from continental slope waters. The lipid values for Calanus finmarchicus are slightly higher than those summarized by MARSHALL \& ORR (1955); as noted by these workers and by Susmoina (1961), the relative fat content of females is less than that of the younger stages. NAKAI (1955) repotted the lipid of Calanus plumchrus and C. cristatus as $31 \%$ to $54 \%$ of the dry weight, and Conover (1962 - subsequent discussion) reported a maximum fat content of C. byperboreus as $65 \%$ of the dry weight. The total lipid content of Meganyctiphanes norvegica is lower than most of the values reported by FisHer (1962), and the lipid content of Limacina ( = Spiratella) retroversa is slightly less than Fisher's value for this species. Orr (1935) reported $21 \%$ to $36 \%$ as the lipid content of Paraeuchaeta (= Euchaeta) norvegica, and NAKAI (1955) reported a value of $40 \%$ for the content of a species of Paratbemisto.

Pristane was present in all of the organisms tested, but it was much more abundant, relative to dry weight or to total lipids, within the genus Calanus than in any other forms. Relative to dry weight, this genus contains at least ten times more pristane than the other genera. 


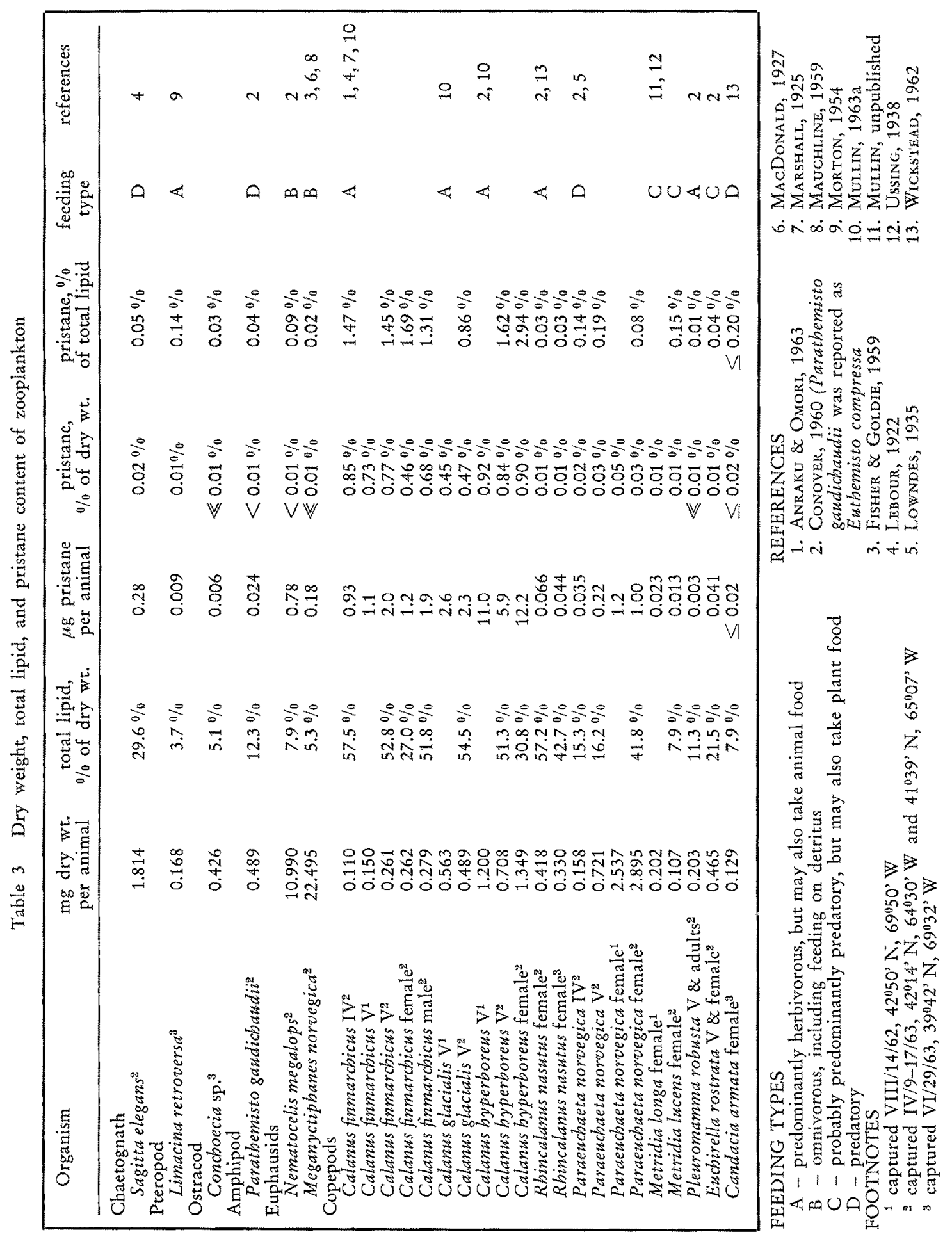


Also indicated in the 'Table are the probable feeding habits of the various species, taken from literature references. From the available evidence, the high pristane content of Calanus cannot be attributed to its diet alone; apparently a biochemical pathway for the concentration or storage of pristane has assumed special importance in this genus but is relatively unimportant in the other herbivorous genera.

Among the predators, Paraenchaeta norvegica had a relatively high pristane content. This may be a direct result of feeding on Calanus. In terms of feeding habits, lipid storage, and phylogeny, the species most similar to Calanus is probably Rhincalanus nasutus, which contained very little pristane. However, the gas chromatogram of animals of this species collected in April in the Gulf of Maine contained a very large peak, approximately four carbon numbers higher than pristane. The corresponding material eluted from silica gel together with the hydrocarbon fraction. It is much more labile than pristane and is destroyed when extracts are stored for two days in the light at room temperature. Rbincalanus was too rare in the Gulf of Maine samples to permit the isolation and complete characterization of this compound. Additional individuals of this species, collected over the continental slope in June, contained only small amounts of this compound. In contrast to the animals from the first location, these animals contained a larger amount of a second unknown, which eluted in the gas chromatogram just before pristane. Thus, it appears that - as in the case of Calanus - Rbincalanus may be characterized by the abundance of specific organic compounds, which furthermore show a large seasonal or geographic variability.

\section{PRISTANE AND LIPID METABOLISM OF CALANUS HYPERBOREUS DURING STARVATION}

In order to investigate the metabolism of pristane by C. byperboreus relative to total lipids, over 200 stage $V$ animals were caught in late May, 1963, and were kept in filtered sea water in the dark at $4^{\circ} \mathrm{C}$ in the laboratory. At 4-day intervals, two groups of three animals each were killed by heating for dry weight and total lipid analysis, and four more by freezing for pristane determinations. After 37 days, twice as many animals were sacrificed every eight days. The animals survived well during the 86 days of the experiment, and the mortality, which was less than $10 \%$, was due largely to unsuccessful molting.

Figure 1 shows the pristane content, total body dry weight, lipid-free dry weight, and lipid content as a function of starvation time. Almost all the weight loss was due to decrease in lipid, supporting CoNOVER's (1962) conclusion that lipids serve as the main metabolic substrate during starvation. The decrease in total body weight of these stage $\mathrm{V}$ animals under starvation conditions in the laboratory is parallelled by a similar weight decrease of animals collected at various intervals during the same period in nature (MuLLIN 1963b).

The experiment indicates that the metabolism of pristane by Calanus during starvation does not follow the pattern of total lipid metabolism. The increase in pristane during the experiment is statistically significant; this effect, if real, suggests that the complete conversion of precursors to pristane is relatively slow. 


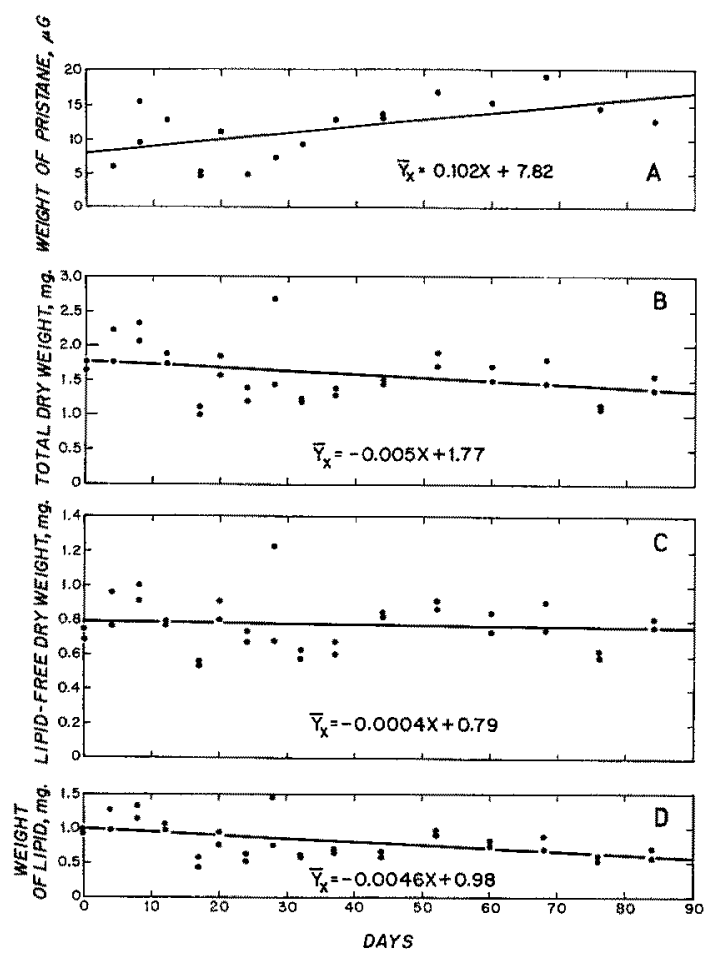

Fig. 1: Weight changes of individual stage $V$ Calanus byperboreus during starvation at $4^{0} \mathrm{C}$. A: Slope significantly different from zero $(p<.01)$; B: Slope significantly different from zero $(.05<p<.1)$; C: Slope not significantly different from zero $(p>.6)$; D: Slope sígnificantly different from zero $(p<.01)$; (probabilities by 2-tailed " $t$ " test)

\section{DISCUSSION}

The branched structure of pristane (Figure 2, I) resembles that of many natural compounds derived from isoprene (2-methyl-1:3-butadiene, II). Natural isoprenoids generally consist of a multiple of five carbon atoms, and the presence in pristane of 19 carbons suggests that pristane is derived from a 20 -carbon compound. As a part of the chlorophyll molecule, phytol $\left(\mathrm{C}_{20} \mathrm{H}_{40} \mathrm{OH}\right.$, III) is present in large amounts in the phytoplankton eaten by herbivorous zooplankton. We suggest that phytol is converted in Calanus and other herbivores to the structurally similar pristane in three steps: hydrogenation of the double bond, oxidation of the alcohol to the acid, and decarboxylation to the saturated hydrocarbon.

The rate of pristane accumulation by Calanus depends - among other factors on the rate of chlorophyll ingestion. This suggests that the pristane level in Calanus might serve as a metabolic indicator for the amount of phytoplankton ingested or assimilated, provided that the efficiency of pristane production and retention remains constant during the life span of the animal. 
<smiles>CCCCCC(C)C(C)CCCCC(C)C(C)CCCCC(C)C</smiles><smiles>C=C(C)C</smiles>

Isoprene<smiles>CCCCCC(C)C(C)CCCC(C)CCCC=CCO</smiles>

Fig. 2: Structural relationship between pristane, isoprene and phytol

The unusual abundance of pristane in Calanus, as compared to other zooplankton, suggests that this molecule may serve some useful function, rather than being merely an incidental metabolic byproduct. Production and retention of pristane by Calanus aids in bouyancy regulation during periods of starvation, although other functions are possible. As pointed out by Conover (1962) and Mullin (1963b), C. byperboreus enters a non-feeding "diapause" during the summer and fall, and C. finmarchicus passes through an inactive period during the winter (MARShall \& ORR 1958, Carlisle \& Pitman 1961). During these periods, the stored lipids are metabolized and the overall density of the animal is increased, leading to increased "waste" of energy by the animal in swimming to maintain itself in the water column. By storing a nonmetabolized, bouyant hydrocarbon (pristane, density 0.78 ) rather than additional metabolizable lipids (approx. density 0.88 ), the animal can make more complete use of the stored lipids. In terms of bouyancy, the presence of $1.0 \mu \mathrm{g}$ of pristane is equivalent to about $1.6 \mu \mathrm{g}$ of average body lipids; thus $1.6 \mu \mathrm{g}$ of lipid are effectively freed for metabolism for each $\mu \mathrm{g}$ of pristane stored. The observation that pristane increased significantly during starvation supports the suggestion that pristane may be of some importance in decreasing the animal's density.

The abundance of specific chemicals in Calanus and in Rhincalanus suggests the possible use of sensitive chemical techniques as taxonomic tools, similar to the use of serology in studying fish and whale populations. Obviously, much more must be learned about the seasonal and geographic distribution of pristane and other hydrocarbons in various zooplankters, as well as their role in metabolism, before hydrocarbon analysis can be applied to taxonomic problems.

Several types of molecules have been followed through various steps in marine food chains, e. g. vitamin A and carotenoids (Kon 1958, Fisher \& Kon 1959, Frsher \& Goldie 1959, Fisher \& Hosking 1962), fatty acids (Lovern 1935, Lasker \& 


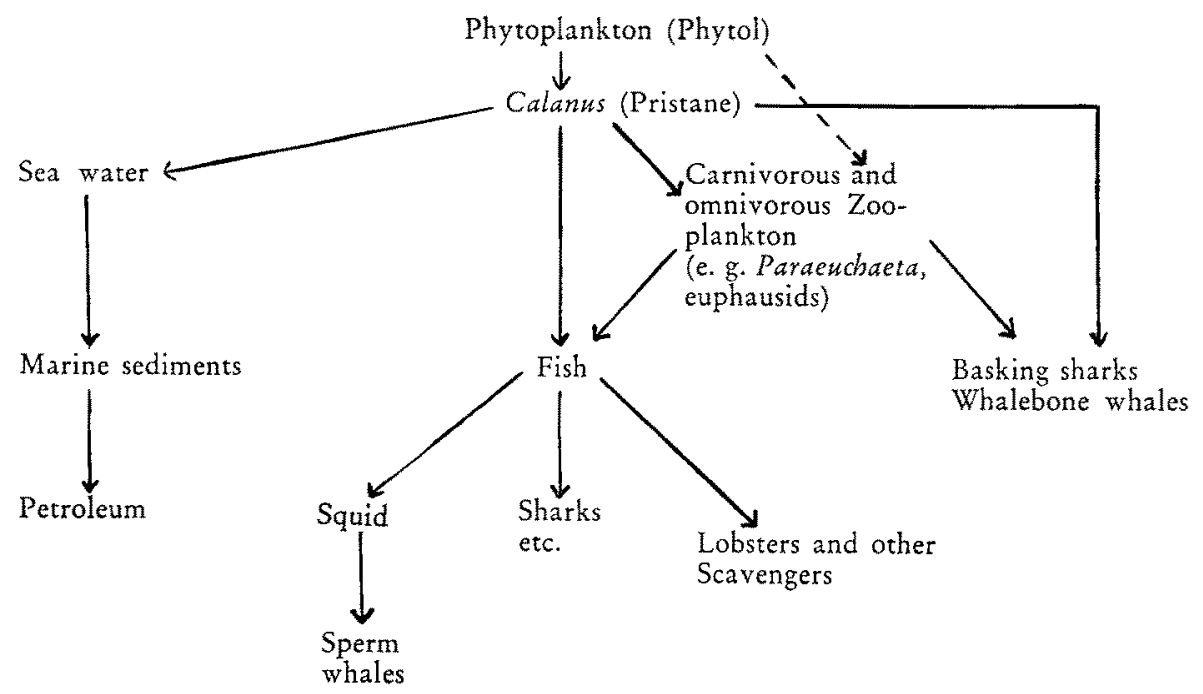

Fig. 3: Pristane in the marine food chain

Thieilacker 1962), and amino acids (Cowey \& Corner 1962, 1963). The present study has cited the occurrence of pristane in nektonic marine carnivores, and it is suggested that Calanus might be a major primary source of this molecule for marine predators. A suggested pathway for pristane in the marine environment is shown in Figure 3. It is possible that the transfer of pristane from Calanus to its predators, e. $\mathrm{g}$. Paraeuchaeta norvegica, and to larger carnivores could be used in studying the dynamics of the marine food chain.

A small fraction of the pristane generated by Calanus may find its way into the sea water, in which it is slightly soluble. During the spring bloom Calanus finmarcbicus in Cape Cod Bay may occasionally reach a density of up to 2000 individuals per cubic meter (ANRAKU 1962). This corresponds to a total pristane production of 2-4 micrograms/1. Sensitive analytical techniques, using solvent extraction and gas chromatography, detect hydrocarbons in sea water at 0.005 micrograms $/ 1$ (BLUMER \& O'JANNE 1962). Thus, the presence in the water of a small fraction of the total pristane produced by Calanus should be detectable. It is of particular interest that Calanus is a predominantly cold-water genus. Consequently, only limited surface areas of the oceans should be tagged with pristane. Other organisms, e. g. Rbincalanus, may conceivably tag other areas with different compounds. The relative stability of hydrocarbons may permit their detection after considerable vertical or horizontal movement from the point of introduction into the water.

Pristane has recently been found to occur at concentrations up to $0.5 \%$ in various crude oils (DEAn \& Whitehead 1961, Bendoraitss et al. 1963) and also in bituminous shales (Cummins \& Robinson 1963). While some of the pristane in sedimentary materials may be derived from organisms related to Calanus, we consider it more likely that most of it is the product of biochemical or geochemical conversions of sedimentary chlorophyll. 


\section{SUMMARY}

1. Methods are described for the sensitive determination of pristane and similar hydrocarbons in individual planktonic organisms and for the isolation of pristane from copepod oil.

2. Pristane $(2,6,10,14$-tetramethylpentadecane) occurs in unusually high concentrations (1-3\% of the body lipid) in Calanus finmarcbicus, $C$. glacialis, and $C$. byperboreus, and at lower concentrations in a wide range of planktonic animals from the Gulf of Maine and continental slope waters.

3. A predator, Paraeuchaeta norvegica, contains pristane at an intermediate level between that of Calanus and the other herbivores, probably as a result of feeding on Calanus.

4. On the basis of relative abundance and structural similarity, phytol is suggested as the precursor of pristane in herbivorous zooplankton.

5. Pristane content is unaltered or increased during the metabolism of the major deposit lipids of Calanus byperboreus during starvation in the laboratory or in nature. Because of its low density, pristane may contribute to the bouyancy of Calanus, especially when the other lipids are metabolized.

6. Pristane may prove useful as a biochemical integrator for the total assimilation of phytoplankton by Calanus.

7. Some planktonic organisms may be characterized by the presence of specific compounds, e. g. pristane in Calanus and several unknown compounds in Rbincalanus.

8. Specific products of organisms of limited geographical occurence may prove useful as biochemical tags of water masses.

\section{ACKNOWLEDGMENTS}

This work was supported by a research contract with the United States Office of Naval Research (Contract Nr. 2196 [00]) and grants from the National Science Foundation (Nrs. 23472 and 23134). The authors are grateful to Dr. K. BIEMANN (Massachusetts Institute of Technology) for the use of his mass spectrometry facility and to Dr. R. J. Conover for the collection of samples. One of the authors (M. M. M.) acknowledges the grant of a NSF predoctoral fellowship.

\section{LITERATURE CITED}

Anraku, M., 1962. Unpublished Manuseript, Woods Hole Oceanographic Institution.

- \& OMORI, M., 1963. Preliminary survey of the relationship between the feeding habit and the structure of the mouth-parts of marine copepods. Limnol. Oceanogr. 8, 116-126.

Bendoraitis, J. G., Brown, B. L. \& Hepner, L. S., 1962. Isoprenoid hydrocarbons in petroleum. Analyt. Chem. 34, 49.

- 1963. Isolation and identification of isoprenoids in petroleum. Proc. 6th World Petroleum Congr., in press.

BLumer, M., 1962. An efficient still for milligram samples of high-boiling materials. Analyt. Chem. 34, 704.

- \& O'JANne, L., 1962. The isolation of dissolved organic compounds from sea water. Abstr. Papers, 142nd Meeting, ACS, Atlantic City, p. $6 \mathrm{~V}$. 
Blumer, M., Mullin, M. M. \& Thomas, D. W., 1963. Pristane in zooplankton. Science 140, 974.

Cahnmann, H. J. \& Kuratsune, M., 1957. Determination of polycyclic aromatic hydrocarbons in oysters collected in polluted water. Analyt. Chem. 29, 1312.

Carlisle, D. B. \& PitMan, W. J., 1961. Diapause, neurosecretion, and hormones in copepoda. Nature, Lond. 190, 827-828.

Ciereszko, L. S., Attaway, D. H. \& Koons, C. B., 1963. On hydrocarbons in gorgonians. Abstr. Papers, 9th Tetrasectional Meeting, ACS, Tulsa.

Clarke, H. T. \& Mazur, A., 1941. The lipids of diatoms. J. biol. Chem. 141, 283.

Collin, G., Drummond, J. C., Hilditen, T. P. \& Gunter, E. R., 1934. Observations on the fatty constituents of marine plankton, II. J. exp. Biol. 11, 198.

Conover, R. J., 1960. The feeding behavior and respiration of some marine planktonic crustacea. Biol. Bull. Woods Hole 119, 399-415.

- 1962. Metabolism and growth in Calanus byperboreus in relation to its life cycle. Rapp. Cons. Explor. Mer. 153, 190-197.

COwex, C. B. \& CoRner, E. D. S., 1962. The amino acid composition of Calanus finmarchicus (Claus) in relation to that of its food. Rapp. Cons. Explor. Mer. 153, 124-128.

- 1963. On the nutrition and metabolism of zooplankton. II. The relationship between the marine copepod Calanus belgolandicus and the particulate material in Plymouth sea water, in terms of amino acid composition. J. Mar. biol. Ass. U. K. 43, 495-511.

Cummins, J. J. \& Robrnson, W. E., 1963. Normal and isoprenoid hydrocarbons isolated from oil-shale bitumen. Abstr. Papers, 145th Meeting, ACS, New York, p. 5 s.

DEAN, R. A. \& WHITEHEAD, E. V., 1961. The occurrence of phytane in petroleum. Tetrahedron Letters, 768.

Emery, K. O., 1960. The sea off southern California. Wiley, New York, 366 pp.

Finnerty, W. R., Hawtrey, E. \& Kallio, R. E., 1962. Alkane-oxidizing micrococci. Z. allg. Mikrobiol. 2/3, 169.

FisHer, L. R., 1962. The total lipid material in some species of marine zooplankton. Rapp. Cons. Explor. Mer. 153, 129-136.

- \& Goldre, E. H., 1959. The food of Meganyctiphanes norvegica (M. SArs), with an assessment of the contributions of its components to the vitamin A reserves of the animals. $J$. Mar. biol. Ass. U. K. 38, 291-312.

- \& Hosking, Z. D., 1962. Vitamin A and fat in the herring (Clupea harengus L.) and in its food. Mar. Res. 1962, 3-35.

- \& Kon, S. K., 1959. Vitamin A in the invertebrates. Biol. Rev. 34, 1-36.

Gerarde, H. W. \& Gerarde, D. F., 1961. The ubiquitous hydrocarbons. Ass. Food and Drug Officials, U. S. 25-26, 1.

KoN, S. K., 1958. Some thoughts on biochemical perspectives in marine biology. In: Perspectives in Marine Biology, edited by Buzzati-Tranerso, Univ. Calif. Press, 283-296.

Lambertsen, G. \& Holman, R. T., 1963. Partial characterization of the hydrocarbons of herring oil. Acta chem. scand. 17, 281.

LASKER, R. \& THEILACKER, G. H., 1962. The fatty acid composition of the lipids of some pacific sardine tissues in relation to ovarian maturation and diet. J. Lipid. Res. 3, 60-64.

LEBour, M. V., 1922. The food of plankton organisms. J. Mar. biol. Ass. U. K. 12, 644-677.

Lederer, E. \& Pliva, J., 1951. Sur le pristane de l'ambre gris. Bull. Soc. Chim. biol., Paris 18, 72.

Lovegrove, T., 1962. The effect of various factors on dry weight values. Rapp. Cons. Explor. Mer. 153, 86-91.

Lovern, J. A., 1935. Fat metabolism in fishes. VI. The fats of some plankton Crustacea. Biochem. J. 29, 847-849.

Lowndes, A. G., 1935. The swimming and feeding of certain calanoid copepods. Proc. zool. Sor. Lond. 1935, 687-715.

Macdonald, R., 1927. Food and habits of Meganyctipbanes norvegica. J. Mar. biol. Ass. U. K. 14, 753-784.

Marshall, S. M., 1924. The food of Calanus finmarchicus during 1923. J. Mar. biol. Ass. U. K. $13,473-479$. 
Marshalt, S. M. \& OrR, A. P., 1955. Biology of a marine copepod. Oliver \& Boyd. Edinburgh, $188 \mathrm{pp}$.

- 1958. On the biology of Calanus finmarchicus. X. Seasonal changes in oxygen consumption. J. Mar. biol. Ass. U. K. 37, 459-472.

MaUchline, J., 1959. The biology of the euphausiid crustacean, Meganyctiphanes norvegica (M. Sars). Proc, roy. Soc. Edinb. (B) 67, 141-179.

Mernschein, W. G., 1959. Origin of petroleum. Bull. Am. Ass. Petrol. Geol. 43, 925.

Monton, J. E., 1954. The biology of Limacina retroversa. J. Mar. biol. Ass. U.K. 33, 297-312.

Mullin, M. M., 1963a. Some factors affecting the feeding of marine copepods of the genus Calanus. Limnol. Oceanogr. 8, 239-250.

- 1963b. Comparative ecology of the genus Calanus in the Gulf of Maine. Ph. D. Thesis, Harvard University.

NAKAI, Z., 1955. The chemical composition, volume, weight, and size of the important marine plankton. Tokai. Reg. Fish. Res. Lab. Spec. Publ. 5, 12-24.

Orr, A. P., 1935. The weight and chemical composition of Euchaeta norvegica Borck. Proc. roy. Soc. Edinb. 54, 51-55.

Pliva, J. \& Sörensen, N. A., 1950. Studies related to pristane, IV. Infrared spectra. Acta chem. scand. 4, 846 .

Schmidt-Nielsen, S. \& Eriksen, K. T., 1944. The liver oils of the basking shark. $K$. norske vidensk. Selsk. Forb. 17, 138.

Smrth, P. V., 1954. Studies on the origin of petroleum. Bull. Am. Ass. Petrol. Geol. 38, 377.

SöRENSEN, N. A. \& Mehlum, J., 1948: Studies related to pristane, I. The unsaponifiable matter of the liver oil of the basking shark. Acta chem. scand. 2, 140.

Sörensen, J. S. \& Sörensen, N. A., 1948. Studies related to pristane, IT. The methyl-octadecanes. Acta chem. scand. 2, 166.

- 1949. Studies related to pristane, III. The identity of norphytane and pristane. Acta chem. scand. 3, 939 .

Stevens, N. P., Bray, E. E. \& Evans, E. D., 1956. Hydrocarbons in sediments of Gulf of Mexico. Bull, Am. Ass. Petrol. Geol. 40, 975.

Stewart, J. E. \& Kallio, R. E., 1959. Bacterial hydrocarbon oxidation, II. J. Bact. 78, 726.

- Stevenson, D. P., Jones, A. C. \& Schissier, D. O., 1959. Bacterial hydrocarbon oxidation, I. J. Bact. 78, 441 .

Sushinin, A. P., 1961. [Vertical distribution of Calanus finmarchicus (GuNN.) and its fat content.] (Engl. Transl.) Dokl. vsesoiuz. Akad, sel.-kboz. Nauk, Lenina 141, 1208-1210.

Thomas, D. W. \& Blumer, M., 1964. Pyrene and fluoranthene in manganese nodules. Science $43,39$.

ToYAma, Y., 1923. A saturated hydrocarbon from shark liver oils. Chem. Umschau 30, 181.

- \& TsuchiYA, T., 1935. A saturated hydrocarbon, "pristane", in sardine, herring and sperm oils. J. Soc. Chim. Japan 38, 254.

T'suchrya, T. \& KANEKO, R., 1951. The unsaponifiable matter of the fatty substance of sperm whale liver, I. Hydrocarbons. J. chem. Soc. Japan 54, 592.

Tsuchiya, T., KaneKo, R. \& Endo, T., 1952. The chemical composition of pristane, I. $J$.chem. Soc. Japan 55, 249.

Tsujno, T. \& KтKUCHI, K., 1953. Low boiling fraction obtained by industrial molecular distillation of basking shark liver oil. J. agric. chem. Soc. Japan 27, 437.

Ussing, H. H., 1938. The biology of some important plankton animals in the fjords of East Greenland. Medd. Grgnland 100, 1-108.

VANDENHEUVEL, F. A, 1963. Quantitative analysis of submicrogram amounts of high boiling compounds by flame ionization gas liquid chromatography. Analyt. Chem. 35, 1186.

WicksteAd, J. H., 1962. Food and feeding in pelagic copepods. Proc. zool. Soc. Lond. 139, $545-555$.

ZecrimersteR, L. \& Koe, B. K., 1952. The isolation of carcinogenic and other polycyclic aromatic hydrocarbons from barnacles. Arch. Biochem. 35, 1. 


\section{Discussion following the paper by BLUMER, MULLIN \& Thomas}

Schaffer: Wie isolieren Sie Pristan aus dem Meerwasser?

Blumer: Die Isolierung von KW-Stoffen, wie Pristan, aus dem Meerwasser sollte relativ einfach sein. Der Verteilungskoeffizient von Pristan gegenüber organischen Lösungsmitteln ist sehr groß, so daß in einer einfachen ein- oder mehrstufigen Extraktion ein vollkommener Ubbergang von Pristan ins Lösungsmittel stattfinden sollte. Nach der Extraktion ist Gaschromatographie die Methode der Wahl.

KINNE: I am particularly interested in the potential importance of pristane as an ecologically significant substance. Are there any indications that pristane might affect intra- or interspecific relationships?

Blumer: I have not mentioned this as a possible additional function of pristane because this is purely speculative, but one wonders whether organisms which feed on Calanus might not be attracted by pristane. MulLIN, co-author of this paper, intends to study in the laboratory whether Calanus are attracted or repelled by pristane introduced into the sea water, but this question is still open.

CRISP: What is the longevity of pristane in sea water? One would expect it to be strongly adsorbed on the sea surface and perhaps therefore to disappear from the sea in this way.

Blumer: R. E. Kallio, who is working on bacterial hydrocarbon oxidation, has studied the degradation of pristane as well of other paraffin hydrocarbons and has found that pristane is attacked by some microbes. Thus, eventually pristane will be oxidized to an acid and then esterified by the bacteria. Pristane is a strongly surface active material, and it is quite likely that it would be absorbed on bubbles and get concentrated in slicks.

ToMcZAK: Sind schon Versuche gemacht worden, Pristan zur Charakterisierung von Wasserkörpern zu verwenden, um durch Konzentration seines Auftretens die Verteilung eines bestimmten Wasserkörpers zu bestimmen?

Buumer: Das haben wir noch nicht getan. Das ist natürlich der nächste Schritt in unserer Arbeit. 